\title{
Effect of opening material granularity on the mould properties and the quality of castings made by patternless process technology
}

Richard Pastirčák, Emil Krivoš

Department of technological engineering. Faculty of Mechanical Engineering, University of Žilina, Univerzitná 1, 01026 Žilina, Slovak Republic.richard.pastircak@fstroj.uniza.sk

Submitted article deals with the methods to improve mould breathability when using the Patternless process method and also examines the influence of opening material grain size on the dimensional and shape precision of made castings. Mentioned methods are based on the principle of direct milling cavity into block from moulding mixture with CNC machining. As the moulding material was used CT moulding compound composed of opening materials SH 35, SH 31 and water glass as binder. The curing process took place by purging $\mathrm{CO}_{2}$ gas through moulding compound. To achieve the highest quality surface cavity was used protective coating PROTECT WC1. The final shape and dimensional accuracy of the castings was evaluated using a 3D measuring device and a contourgraph.

Keywords: Patternless process, mould cavity, opening material

\section{Acknowledgements}

This work was created within the solution of the grant project VEGA no. 1/0610/12, VEGA no. 1/0785/13 focusing on technology and simulation for applications in manufacturing and KEGA no. 006ŽU-4/201. The authors thank the Grant Agency for support.

\section{References}

[1] PASTIRČÁK, R., BOLIBRUCHOVÁ, D., SLÁDEK, A. (2009). Casting theory. Žilina: ŽU v Žiline, Georg, 2009,155 pp. ISBN 978-80-89401-04-08

[2] PASTIRČÁK, R., URGELA, D., KRIVOŠ, E.: Production of castings by patternless process. In.: Archives of foundry engineering. ISSN 1897-3310, 2012, Vol. 12, Iss. 1(2012), pp. 87-92.

[3] PASTIRČÁK, R., URGELA, D.: Device for production of prototype moulds by milling. In: Archives of foundry engineering. ISSN 1897-3310, 2011, Vol. 11, Spec. Iss. 1 (2011), pp. 45-50.

[4] BABU, T. S., THUMBANGA, R. D. (2011). Reverse engineering, cad/cam \& patternless process applications in casting. In International Journal of Mechanics. ISSN 1999-4448, 2011, vol. 5, no. 1, pp. 40-47.

[5] RODRÍGUEZ, A. et al. (2012). Maximal reduction of steps for iron casting one-of-a-kind parts. In Journal of Cleaner Production. ISSN 0959-6526, 2012, vol. 20, no. 24, pp. 48-55.

[6] PASTIRČĆK, R., URGELA, D.: Construction of milling machine for production moulds made by patternless process. In: TRANSCOM 2011: 9-th European conference of young research and scientific workers : Žilina, June 27-29, 2011, Slovak Republic. - Žilina: University of Žilina, 2011, ISBN 978-80-554-0374-8, pp. 151-154.

[7] KANTORÍK, R., BOLIBRUCHOVÁ, D.: Free melt surface monitoring with the help of metal flow simulation in moulds. In: International Foundry Research 2011, volume 63, issue 2, pp. 18 - 23, ISSN 0046 - 5933.

[8] BOLIBRUCHOVÁ, D., SLÁDEK, A., BRU゚NA, M. (2010). Effect of filtration on reoxidation proceses in aluminium alloys. Archives of foundry engineering. ISSN 1897-3310. - Vol. 10, Spec. Issue 1, pp. 121-126.

[9] BOLIBRUCHOVA, D. (2010). Casting technology: GEORG Žilina, ISBN 978-80-89401-14-7, 248 pp.

[10] BRŮNA, M., BOLIBRUCHOVÁ, D., KANTORÍK, R.: Filtration of aluminium alloys and its influence on mechanical properties and shape of eutectical silicium. In: Archives of foundry engineering. ISSN $1897-3310$, Vol. 8, issue 2 (2008), pp. 13-16.

[11] LIPIŃSKI, T. 2011. Use Properties of the AlSi9Mg Alloy With Exothermical Modifier. In Manufacturing Technology, Vol. 11, No. 11. pp. 44-49. ISSN 1213-2489.

[12] WEISS, V., STRIHAVKOVA, E.: Influence of the homogenization annealing on microstructure and mechanical properties of AlZn5.5Mg2.5Cu1.5 alloy. In: Manufacturing Technology, Volume 12, 2012, No. 13. ISSN 1213-2489, pp. 297 - 302. 